\title{
Konstruksi perempuan dan gender dalam gerakan Tarbiyah di kampus-kampus universitas negeri di Surabaya: sebuah modalitas pembangunan karakter bangsa
}

\author{
Construction of female and gender in Tarbiyah movement in \\ campuses of public universities in Surabaya: A modality for \\ nation character building
}

\author{
Diah Ariani Arimbi \\ Fakultas Ilmu Budaya, Universitas Airlangga, Surabaya \\ Jalan Dharmawangsa Dalam, Surabaya 60286, Indonesia \\ E-mail: diaharimbi@yahoo.com
}

\begin{abstract}
The Tarbiyah (education) movement in Indonesia today is the best known and has the largest number of members amongst groups in the Dakwah (proselytising) movement that mostly work in Indonesian campuses. However, in contrast to other Islamic revivalist organizations, the Tarbiyah movement, is reformist, and relies heavily on modern interpretations of Islam concerned with democracy, civil society, human rights and equality of women, although these values are understood differently from common Western notions. The group has many female activists but unfortunately until today there has never been any study looking at the ways women has involved in this Tarbiyah movement. This paper aims to explore the numerous and varieties of women's activities in this movement, especially in relation the ways women see their rights, roles and sexual identities within their notion of piety. Female and male activists of Tarbiyah movement in Airlangga University (UNAIR), Surabaya State University (UNESA) and Institute of Technology Surabaya (ITS) are respondents in this research. Participation observation and in-depth interviews will used as techniques of data collection. Some finding shows that the Tarbiyah movement's espousal of women's and gender issues in an Islamic setting complicates even more the dissemination of such issues to the Indonesian public. One important finding indicates that the Tarbiyah conceives that male and female are segregated in nature (biological construction) yet in that segregation lies irreplaceable equality in any sphere and any value. Although many female members of the Tarbiyah movement claim to reject feminism, in particular they reject liberation of women's (and men's) sexuality, as it is believed to be of Western origin, in fact they subscribe to concepts of sexual equality while maintaining sexual segregation. The rise of the Dakwah movement and its various groups has raised concern in Indonesian society that such groups may pose a threat to civil Islam. However, to see all groups in the Dakwah movement as militant, radical or even fundamentalist is wrong, the complexity of Islamic movements requires careful examination as within these movements groups are fragmented in terms of their interpretations of Islam and its application. Teaching of this Dakwah movement can also be an alternative to national character building as its teachings and morale are in accordance to the values of Indonesian national characters such as honesty, religiousness and others.
\end{abstract}

Keywords: Islam, Tarbiyah movement, women, rights, roles, equality, national character

\begin{abstract}
Abstrak
Tarbiyah (pendidikan) gerakan di Indonesia saat ini adalah yang paling dikenal dan memiliki jumlah terbesar dari anggota antara kelompok-kelompok dalam gerakan dakwah yang sebagian besar bekerja di kampus Indonesia, namun berbeda dengan organisasi revivalis lainnya Islam, gerakan Tarbiyah adalah reformis dan sangat bergantung pada interpretasi modern dari Islam peduli dengan demokrasi, masyarakat sipil, hak asasi manusia dan kesetaraan perempuan, meskipun nilai-nilai ini dipahami secara berbeda dari gagasan Barat yang umum. Kelompok ini memiliki banyak aktivis perempuan, tetapi sayangnya hingga saat ini belum pernah ada setiap penelitian yang mengamati cara perempuan telah terlibat dalam gerakan Tarbiyah ini. Artikel ini bertujuan untuk mengeksplorasi banyak variasi dan kegiatan perempuan dalam gerakan ini, terutama dalam kaitannya dengan cara wanita melihat hakhak mereka, peran dan identitas seksual dalam pengertian mereka kesalehan. aktivis perempuan dan
\end{abstract}


laki-laki dari gerakan Tarbiyah di Universitas Airlangga (UNAIR), Universitas Negeri Surabaya (UNESA) dan Institut Teknologi Surabaya (ITS) yang responden dalam penelitian ini. Observasi partisipasi dan wawancara mendalam akan digunakan sebagai teknik pengumpulan data. Beberapa temuan menunjukkan bahwa pendukung gerakan Tarbiyah tentang perempuan dan isu-isu gender dalam pengaturan Islam mempersulit bahkan lebih penyebaran isu-isu tersebut kepada masyarakat Indonesia. Salah satu temuan penting menunjukkan bahwa Tarbiyah laki-laki dan perempuan dipisahkan di alam (konstruksi biologis), namun dalam segregasi yang terletak kesetaraan tak tergantikan dalam lingkup dan nilai apapun. Meskipun banyak anggota perempuan dari gerakan klaim Tarbiyah untuk menolak feminisme, khususnya mereka menolak pembebasan perempuan dan laki-laki, seperti yang diyakini berasal dari Barat, pada kenyataannya mereka berlangganan konsep kesetaraan seksual tetap menjaga pemisahan seksual. Munculnya gerakan dakwah dan berbagai kelompok yang telah menimbulkan kekhawatiran di masyarakat Indonesia bahwa kelompok-kelompok tersebut dapat menimbulkan ancaman bagi Islam sipil, namun untuk melihat semua kelompok dalam gerakan dakwah sebagai militan, radikal atau bahkan fundamentalis yang salah, kompleksitas gerakan Islam memerlukan pemeriksaan hati-hati karena dalam gerakan kelompok-kelompok yang terpecah-pecah dalam hal interpretasi mereka tentang Islam dan aplikasinya. Pengajaran gerakan Dakwah ini juga dapat menjadi alternatif untuk pembangunan karakter nasional ajaran-ajarannya dan moral yang sesuai dengan nilai-nilai karakter nasional Indonesia seperti kejujuran, religiusitas dan lain-lain.

Kata kunci: Islam, gerakan Tarbiyah, perempuan, hak, peran, kesetaraan, karakter nasional

\section{Pendahuluan}

Gerakan feminisme Islam di Indonesia yang mulai muncul di tahun 90an ini (Istiadah 1995), ternyata bukan hanya satu-satunya gerakan keIslaman dalam periode Orde Baru. Tahun 1980an menjadi awal munculnya gerakan revivalisasi (penghidupan kembali) Islam yang memang sebelumnya juga telah ada. Salah satunya adalah gerakan Dakwah yang berawal di kampus-kampus universitas sekuler, seperti di ITB (Institut Teknologi Bandung). Gerakan Dakwah seperti ini sendiri bukanlah gerakan yang homogen, di dalamnya terdapat segmentasi seperti Hizbut Tahrir, Darul Arqam, and Tarbiyah (pendidikan) yang berpusat pada kampuskampus universitas.

Adalah gerakan Tarbiyah yang lebih dikenal publik Indonesia dan yang paling banyak mempunyai anggota terutama para mahasiswa dan mahasiswi yang aktif dalam kegiatan masjid kampus atau SKI (Sie Kerohanian Islam). Tarbiyah atau lebih dikenal sebagai "Kampus Islam," beranggota terutama para mahasiswa dan lulusan yang memulai pendidikan mereka atau "indoktrinasi" di Masjid Salman, ITB (Bruinessen 2003) di tahun 1980an, yang kemudian menginspirasi aktivitas-aktivitas yang sama di berbagai tempat, terutama di kampus-kampus "sekuler" (Bruinessen 2003).

Tidak seperti hampir semua gerakan sosial di dunia atau di Indonesia pada khususnya, gerakan Tarbiyah ternyata tidak hanya berkisar pada gerakan sosial saja, gerakan ini ternyata juga meliputi wilayah agama atau kesalehan. Oleh karena sangat penting untuk melihat bahwa dalam mobilitas sosial yang terjadi lewat gerakan ini, wilayah agama atau kesalehan (piety) menjadi penanda yang sangat penting dalam menunjukkan adanya politisasi yang berujung pada hubungan eksternal tidak hanya antara individu dan agama dalam wilayah privat tetapi juga individu, agama dan sosial dalam wilayah publik. Gerakan jilbabisasi di kampus-kampus sekuler contohnya, dipandang sebagai wujud kebebasan dan ekspresi beragama baik dalam wilayah privat (hak pribadi seseorang dalam menunjukkan kesalehan ia pada agama yang ia anut) tetapi juga menyentuh wilayah publik karena perempuan memakai jilbab apabila dia berada di wilayah publik (Brenner 1996, Guindi 1999, Cooke 2000, Carpenter 2001). Dari contoh kecil ini saja, bisa terlihat adanya politics of piety atau politik kesalehan terjadi.

Dalam gerakan ini terdapat banyak perempuan yang menjadi aktivis dan meskipun dalam setiap pertemuan perempuan dan laki-laki terpisah dengan jalan masuk yang berbeda pula, perempuan tidak duduk di belakang laki-laki, mereka duduk setara dengan laki-laki walau 
terpisah tempatnya. Dalam pemilihan anggota parlemen di Pemilu tahun 2004, PKS (Partai Keadilan Sejahtera) yang anggota utamanya adalah juga para anggota Tarbiyah, mengalokasikan jumlah perempuan untuk menjadi anggota parlemen tertinggi dibanding dengan partai-partai lainnya (Islami maupun non Islami), bahkan jumlahnya melewati quota 30\% (Pikiran Rakyat, 17 Januari 2004).

Munculnya gerakan Tarbiyah ternyata semakin menunjukkan kompleksitas isu-isu yang mengangkat perempuan dan peranan mereka dalam Islam. Sayangnya masih sedikit sekali kupasan, riset maupun tulisan-tulisan yang membahas peranan perempuan dalam gerakan ini. Lebih banyak ditemukan dalam rangka hubungan peranan perempuan dan Islam adalah dalam bentuk buku panduan: buku-buku yang memberikan model atau kiat-kiat bagaimana menjadi Muslimah yang saleha atau perempuan yang sakina tanpa memberikan ulasan yang lebih dalam tentang kompleksitas peranan perempuan dalam Islam (Abubakar 2002, Meuleman 1993). Tulisan-tulisan yang ada umumnya membahas gerakan ini secara general dan hampir tidak ada yang membahas secara khusus wacana perempuan dan peranan mereka dalam gerakan Tarbiyah.

Penelitian ini bertujuan untuk konstruksi perempuan dan gender dalam kehidupan kampus. Gerakan Tarbiyah adalah gerakan pendidikan oleh karena itu tidak heran kalau gerakan ini berada terutama dalam lingkungan pendidikan yaitu lingkungan kampus. Dalam penelitian ini, kontruksi perempuan dan gender yang muncul akan ada menjadi fokus utama serta bagaimana konstruksi tersebut menjadi satu modalitas pembangunan karakter bangsa. Permasalahan yang muncul seperti arti Gerakan Tarbiyah, di Indonesia khususnya, sebagai bagian dari Islamic Youth Movements (gerakan anak muda Islami), historiografi gerakan Tarbiyah di Indonesia, peranan perempuan, isu-isu perempuan serta wawasan akan kesetaraan jender dalam wacana gerakan ini akan dibahas melalui analisa terhadap hasil wawancara mendalam 30 orang aktivis Universitas Airlangga (UNAIR), Universitas Negeri Surabaya (UNESA) dan Institut Teknologi Surabaya (ITS). Wawancara dan observasi dilakukan selama bulan Maret - Juli 2015. Masing masing wawancara yang berlangsung lebih kurang $60-90$ menit direkam dan kemudian ditanskripkan. Transkrip dan rekaman menjadi sumber data utama sedangkan sumber data sekunder berasal dari buku, sumber online dan sebagainya. Melalui kacamata feminisme Islam terutama yang menyangkut isu-isu perempuan dan relasi gender, hasil wawancara tersebut dianalisa dan dicari temuannya.

\section{Feminisme Islam}

Secara umum, Feminisme Islam melihat bahwa walaupun Islam berperan sebagai agama yang lebih banyak menyentuh wilayah privat tetapi practiced Islam yaitu Islam dan ajaranajarannya yang dilaksanakan dalam kehidupan sehari hari tidak bisa lepas dari berbagai situasi politis, kultural, sosial dan budaya dari masyarakat yang ada (Tim Risalah Gusti 2000). Oleh sebab itu definisi Feminisme Islam tidaklah monolitik tetapi menurut Yamani (1996):

\footnotetext{
"Such feminism is unique in conjuring up delicate and challenging issues for political and religious authorities as well as for scholars in a world of a billion Muslims. Within that new overarching background which deals with Islamic laws and traditions, the category of "Islamic feminism" may stand its ground by the sheer diversity it includes: contributors to the debate have been considered "new feminist traditionalists, "pragmatists", "secular feminists", "neo-Islamists", and so forth. For all these thinkers, however, there is a common concern with the empowerment of their gender within a rethought Islam.
}

Kutipan Yamani menunjukkan bahwa feminisme dalam Islam mempunyai arti yang jamak, atau plural. Dengan kentalnya nilai-nilai keIslaman yang menjadi konteks Feminisme Islam tidaklah mengherankan apabila Feminisme Islam juga merupakan bagian dari Feminist 
Theology (feminisme teologi), seperti yang dikatakan oleh Riffaat Hassan dari Pakistan (Hassan 1996):

The importance of developing what the West calls "feminist theology" in the context of the Islamic tradition is paramount today in order to liberate not only Muslim women, but also Muslim men, from unjust social structures and systems of thought that make a peer relationship between men and women impossible. It is extremely important for Muslim women activists to realize that in the contemporary Muslim world, laws instituted in the name of Islam cannot be overturned by means of political action alone, but through the use of better religious arguments. . . [B]y means of feminist theology it is possible to equip and empower women to combat gender-inequality and injustice to which they have been subjected for a very long time.

Dengan kentalnya unsur keagamaan dalam gerakan perempuan, Feminisme Islam juga menandai munculnya politics of piety karena dengan melalui kesalehan dalam beragama maka keadilan, kebebasan dan kesetaraan bisa tercapai.

Yang lebih penting adalah memberikan ruang bagi perempuan untuk menentukan pilihan mereka sendiri atas dasar kesadaran diri sendiri, seperti yang dikatakan oleh Didin Syafrudin (1994):

The drive in interpreting Al Qur'an is not to interpret women in male interpretations in biological, psychological or sociological meaning, but to make possibilities for women to act in their own free and conscious choices just like men. That women have traditional role or completely new role is not the problem. What matters is that women are free to choose and have their own decision.

Dengan demikian, penelitian seperti ini sangat penting untuk pula sekaligus menunjukkan bahwa pola-pola atau model-model peranan perempuan dalam gerakan Tarbiyah di Indonesia bisa memberikan warna yang mungkin sama atau berbeda dengan gerakan serupa di tempat lain. Partisipasi aktif perempuan dalam gerakan ini menunjukkan bahwa mereka juga mempunyai pilihan dalam mengikuti peranan-peranan publik.

\section{Terminologi dan historiografi}

Gerakan Tarbiyah, sebagaimana yang dipaparkan oleh salah satu responden adalah gerakan pendidikan yang seperti pada gerakan lainnya bertujuan untuk memberikan pendidikan terutama pendidikan keIslaman kepada para penganutnya (anggota Tarbiyah). Gerakan yang bermula di dalam masyarakat kampus di masjid di ITB awal tahun 1990an akhirnya menyebar ke berbagai kampus di seluruh Indonesia. Menurut Wikipedia, Tarbiyah sendiri mempunyai arti yang jamak. Kutipan panjang dari Wikipedia adalah sebagai berikut:

\footnotetext{
"Tarbiyah berasal dari bahasa Arab yang berarti pendidikan, sedangkan orang yang mendidik dinamakan Murobi. Secara umum, Tarbiyah dapat dikembalikan kepada 3 kata kerja yg berbeda, yakni: 1) Rabaa-yarbuu yg bermakna namaa-yanmuu, artinya berkembang. 2) Rabiya-yarbaa yg bermakna nasya-a, tara'ra-a, artinya tumbuh. 3) Rabba-yarubbu yg bermakna aslahahu, tawallaa amrahu, sasa-ahuu, wa qaama 'alaihi, wa ra'aahu, yang artinya masing memperbaiki, mengurus, memimpin, menjaga dan memeliharanya (atau mendidik).
}

Gerakan Tarbiyah adalah gerakan yang mendidik. Menurut KH Rahmat Abdullah dalam publikasi acara Seminar Nasional "Tarbiyah di Era Baru” di Masjid UI, Kampus UI Depok, pengertian Tarbiyah (pendidikan) ini tidak menafikan proses Tarbiyah yang terjadi di Indonesia sejak dulu. Tanpa proses Tarbiyah, bagaimana mungkin walisongo dapat 
melahirkan pejuang-pejuang handal. Apapun namanya, apakah itu pengkaderan dengan ' $\mathrm{t}$ ' kecil (Tarbiyah), yang jelas itu adalah proses pendidikan.

Inilah yang disebut kelompok kajian yang mengandung 3 unsur utama. Pertama, yang mengandung atmosfir dzikir dan ibadah atau aspek rohaniah spiritual. Kedua, aspek fikriyah, keilmuan. Yang ketiga, aspek dakwah harakiyah, yakni implementasi dari yang pertama dan kedua. Proses yang demikian pada saatnya akan sampai pada satu titik, di mana mereka siap untuk berinteraksi dengan masyarakat dengan bekal dan kekuatan yang memadai sehingga tidak mudah larut, tapi malah bisa menciptakan perubahan (Syaikhut 2007). Tarbiyah di sini merujuk kepada sebuah gerakan Islam yang masuk ke Indonesia dalam kurun waktu dua puluhan tahun belakangan ini. Meski demikian, Ustadz Rahmat Abdullah, yang dijuluki sebagai syaikhut Tarbiyah Indonesia, agak sedikit keberatan ketika mendengar ada pihak yang mengklaim bahwa proses Tarbiyah di Indonesia hanya dibatasi dalam kurun waktu dua puluhan tahun belakangan ini. Menurutnya, hal ini tidak bisa diterima karena proses Tarbiyah telah berlangsung selama berabad-abad di Indonesia dan bukan hanya terjadi dua puluhan tahun belakangan ini saja. Penyebaran Islam di Indonesia telah berjalan berabad-abad, sedangkan setiap penyebaran Islam di bumi manapun pastilah dilakukan melalui proses Tarbiyah. Jika memang mau memaksakan penggunaan istilah Tarbiyah untuk menggambarkan sebuah gerakan yang baru masuk ke Indonesia sekitar dua puluhan tahun tersebut, maka Ustadz Rahmat Abdullah mempersyaratkan untuk mengganti huruf 't' kecil dalam kata Tarbiyah menjadi huruf ' $T$ ' besar (lihat kutipan diatas). Hal ini dimaksudkan untuk menunjukkan bahwa Tarbiyah bukanlah Tarbiyah. Tarbiyah merujuk kepada suatu aturan, sistem dan ideologi tertentu yang memasuki Indonesia dua puluhan tahun belakangan ini, bukan kepada makna Tarbiyah yang biasa digunakan oleh umumnya ummat Islam. Kelompok Tarbiyah di Indonesia merupakan pelaksana dari pemikiran-pemikiran dan ideologi Ikhwanul Muslimin yang didirikan oleh mendiang Hasan Al Banna pada tahun 1928. Kelompok Tarbiyah memfokuskan pembinaan kadernya melalui forum-forum sel yang dinamakan liqo' (sekitar tahun 80an dan awal 90an, forum seperti ini dinamakan usrah). Forum ini biasanya dilaksanakan secara mingguan dan dipandu oleh seorang murabbi (guru) dan diikuti oleh sekitar sepuluh mutarabbi (peserta pendidikan). Model pembinaan seperti inilah yang menjadi ciri khas kelompok Tarbiyah di Indonesia, pun di seluruh belahan dunia (Dayat 2008).

Dengan menggunakan slogan "menjalin ukuwah memperluas cakrawala" gerakan ini, lewat visi dan misinya" memberikan kalim bahwa gerakan ini merupakan gerakan sipil yang sangat erat dengan pembentukan civil society (masyarakat madani). Jika dicermati lebih dalam, gerakan ini tidak berbeda dengan gerakan humanis lainnya karena secara wacana kebahasaan, pilihan kata yang dipakai adalah kata-kata yang sangat umum bagi semua gerakan di dunia baik yang berafilisi agama maupun yang secular yang bertujuan untuk mendapatkan kesetaraan. Kata-kata seperti damai, ramah, sejuk, agung, selarasnya iman, ilmu dan teknologi, keberpihakan pada kaum marginal, perjuangan terhadap kejahatan, menunjukkan bahwa gerakan ini juga mengandung nilai-nilai universal yang sangat umum bagi semua penduduk di dunia. Seperti gerakan Islam lainnya, kata-kata dalam bahasa Arab sangat kental dalam gerakan ini. Hampir semua istilah menggunakan bahasa Arab yang menunjukkan kedekatan gerakan ini dengan dunia Arab (i.e. Ihkwanul Muslim dari Mesir), tetapi cukup berbeda dengan gerakan humanis lainnya (seperti gerakan feminis, gerakan hak-hak sipil), gerakan Tarbiyah mengusung nilai-nilai keagamaan (Islam) secara kental dan sangat berorientasi ke masa lalu. Konteks kekinian nampaknya tidak lagi menjadi penting bagi tujuan, visi dan misi gerakan ini walaupun gerakan ini mengakui bahwa perkembangan ilmu dan teknologi adalah sesuatu yang harus dirangkul dan bukan dimusuhi. Jaman emas kekhalifahan Islam menjadi model terciptanya masyarakat madani di dalam masyarakat di mana gerakan ini berada. Karena fokusnya yanga sangat kuat pada jaman keemasan Islam, gerakan ini tidak memasukkan konflik serta dinamika yang terjadi dalam jaman keemasan tersebut. Sekali lagi, konteks nilai-nilai universal yang mereka usung lebih merujuk pada jaman keemasan Islam dan tidak pada jaman sekarang. Mungkin dalam gerakan ini, dinamika masyarakat, kontestasi, negosiasi dan hegemoni menjadi tidak penting, terutama apabila 
berkaitan dengan konteks peristiwa dan kungkungan time and space. Konteks waktu dan tempat seakan hilang (dalam arti Keindonesiaan atau waktu dan tempat di Indonesia/konteks lokalitas). Hal ini sejalah dengan pendapat Ali Said Damanik yang mengatakan bahwa di Indonesia meski dapat digolongkan sebagai bagian gerakan modernisme Islam, kelompok yang mulai sebagai "Gerakan Dakwah Kampus (GDK)" ini, agak sulit dicarikan akar hubungannya dengan gerakan keagamaan Islam yang pernah ada di Indonesia pada masa lalu. Kehadiran gerakan ini berhubungan erat dengan pengaruh gerakan Islam Internasional yang berkembang di Mesir, yaitu Ikhwanul Muslimin, yang dalam dua dasawarsa terakhir abad ke20 pengaruhnya sangat terasa di berbagai negara di dunia. Dalam kurun waktu tersebut, gerakan yang dimotori oleh anak-anak muda terdidik yang berbasis di perkotaan ini mampu memberi andil dalam proses pembentukan opini dan kecenderungan religiokultural publik. Diterimanya secara luas simbol-simbol keagamaan, seperti pemakaian busana muslimah (jilbab), adalah salah satu dari keberhasilan gerakan ini. Setelah lebih dari satu dasawarsa bergerak di bidang ini maka, bersama dengan terciptanya momentum reformasi, gerakan ini membidik perjuangan struktural pada level negara, dengan mendirikan Partai Keadilan. Sejak itu, Partai Keadilan menjadi fenomena tersendiri dalam langit perpolitikan Indonesia (Damanik 2002).

Seperti penjelasan di atas, pengikut gerakan ini sebagian besar adalah anggota masyarakat kampus (mahasiswa) yang biasanya disapa dalam sebutan akhwat yang berarti sisters (saudari perempuan) dan akhwan yang berarti brothers (saudara laki-laki) tanpa menunjukkan adanya perbedaan usia, latar belakang sosial dan sebagainya. Hal ini menandai adanya demokratisasi dalam sapaan pengikut gerakan ini walaupun dalam berinteraksi mereka sangat terpisah. Laki-laki dan perempuan duduk dalam ruangan yang berbeda atau dalam ruangan yang sama dan dibatasi hijab atau pembatas. Ruang laki-laki adalah ruang publik dan ruang perempuan adalah ruang domestik merupakan ajaran utama gerakan ini. Lalu bagaimana model konstruksi perempuan dalam gerakan ini, apakah terdapat perbedaan dengan gerakan feminis Islam yang ada? Pertanyaan pertanyaan tersebut akan dibahas dalam uraian berikut berdasarkan wawancara dari para pengikut gerakan ini yang merupakan bagian dari Islamic Youth Movements karena sebagian besar anggotanya adalah mereka yang berada dalam usia sekolah maupun mahasiswa.

Sangatlah menarik untuk dicermati bagaimana anggota Gerakan Tarbiyah sekarang ini (2015) mengidentifikasi diri mereka terutama setelah adanya gonjang-ganjing PKS dengan ditangkapnya Ketua PKS atas kasus korupsi daging sapi tahun 2013. Banyak pertanyaan yang muncul apakah setelah kasus tersebut PKS masih mempunyai ikatan kuat dengan Gerakan Tarbiyah. Seperti layaknya gerakan lain, ternyata Gerakan Tarbiyah ini juga mengalami perubahan. Terdapat pro dan kontra tentang afiliasi Tarbiyah dengan PKS setelah munculnya kasus korupsi ketua PKS. Banyak yang pro bahwa PKS adalah alat politik gerakan Trabiyah tetapi banyak juga yang kontra terhadap keterkaitan PKS dan Gerakan Tarbiyah. Bahkan ada situs yang dengan tegas menolak bahwa Tarbiyah bukan PKS: Mencermati opini-opini yang muncul dari situs ini sungguh menarik karena kasus-kasus yang kontemporer dengan cepat ditanggapi oleh para aktivis maupun anggota Tarbiyah yang tergabung dalam situs ini. Sayangnya untuk kepentingan penelitian ini maka sumber data utama tidak diambil mereka yang memberikan komentar pada situs ini tetapi lebih memfokuskan pada para aktivis Dakwah Kampus yang menjadi bagian utama dari Gerakan Tarbiyah ini (Tarbiyah bukan KPS).

\section{Kepemimpinan perempuan}

Tempat utama perempuan adalah di ruang domestik begitu menurut para anggota gerakan Tarbiyah walaupun didapati banyak sekali anggota perempuan yang terlibat dalam kegiatan publik. Kontradiksi seperti ini nampaknya tidak menjadi masalah bagi mereka karena menurut halaqah atau kajian-kajian yang mereka laksanakan secara rutin, perempuan adalah 
pelengkap laki-laki. Perempuan hanya boleh menjadi wakil pimpinan di mana laki-laki lebih utama sebagai pemimpin. Yang lebih menarik adalah bahwa dalam pandangan para anggota Tarbiyah ini, lelaki dan perempuan tetap harus bekerja sama dalam berorganisasi. Berikut wawancara dengan anggota Tarbiyah laki-laki, seperti kata Must:

Konsep gender di mana ini diaplikasikan dalam kegiatan UKKI [UNESA] ini ya. Yang namanya kegiatan tentu ada yang namanya perencanaan dulu, ada rapat. Itu pun sudah dilakukan kalau di sini menyebutnya ikhwan dan akhwat. Nah itu ada di dalamnya hijab, jadi tidak boleh saling pandang satu sama lain tidak boleh. Cuma, makanya di sini itu yang namanya struktur organisasinya contohnya ada kadepkadep. Kalau di sini itu yang namanya struktur organisasi ada yang namanya kadep ada yang namanya wakadep. Kadep dan juga wakadep, kadepnya adalah laki-laki dan wakadepnya adalah perempuan, ini dalam hal pembinaan kan kita dalam organisasi juga membina yang namanya kita kan. Sedangkan di sini anggotanya itu ada yang namanya anggota laki-laki dan anggota perempuan. Yang membina laki-laki ya kadepnya, nah perempuan yang membina adalah wakdepnya. Tapi keduanya tetep bersinergi artinya satu presepsi, tidak mungkin maksudnya kadep itu membina anggota yang permpuan, kan istilahnya tidak etis. Jadi makanya di sini itu sampai bidang itu juga ada wakil bidangnya, nah itu yang pertama terkait perencaanaan, jadi ada hijab satu sama lain. Ketika rapat ada hijab terus masuk pembinaan tadi kadep dan wakdep juga kabid dan wakabid, itu terkait struktur organisasinya. Termasuk kemudian terkait kegiatan misalnya itu kajian dan seterusnya itu ada hijabnya. hijab itu tetep dibawa kemana-mana seperti itu. Tapi kadang bila tidak memungkinkan termasuk acara-acara pelatihan dan sebagainya itu kan kadang menyewa tempat lain tidak hanya di dalam masjid. Sewa gedung di sana dan sebagainya, ya itu mau tidak mau sewa gedungnya harus dilepas. Tapi gak boleh ikhwan dan akhwat duduk dalam satu kursi itu tidak boleh. Mungkin yang bagian kanan ini laki-laki dan yang bagian kiri ini adalah perempuan, walaupun tidak ada hijabnya. Hijabnya ya menghijabi diri sendiri aja lah. Hijabnya kalau di kelas kan tidak ada hijabnya seperti itu.

Dari hasil wawancara di atas terlihat jelas bahwa antara pemikiran ideal dan praktek sangat berbeda. Meskipun perempuan tidak boleh menjadi pemimpin kelompok seperti ketua tetapi mereka boleh menjadi wakil pemimpin: artinya keberadaan perempuan dalam wilayah publik tetap diakui.

Dari pihak aktivis perempuanku juga menunjukkan hal yang sama, seperti kata Fajr.:

Laki- laki itu seorang pemimpin, jadi apapun kedudukannya dia tetap merupakan amanahnya sebagai seorang pemimpin. Sedangkan perempuan adalah pendamping dari pemimpin itu sendiri. Jadi setinggi apapun perempuan sehebat apapun perempuan ya tetap posisinya tetap menjadi pimpinannya laki- laki.

Menurut Okt.:

Kalau laki- laki itu ya berarti, ya kalo dalam Islam itu kan dianjurkan yang jadi pemimpin itu adalah laki- laki, tapi kalau dalam demokrasi kan nggak harus yang jadi pemimpin itu laki- laki gitu. Tapi yang namanya laki- laki kan ya paling tidak kan dia sebagai pemimpin dalam rumah tangga, kalau menurut saya laki- laki itu ya seperti ayah, perempuan ya kayak ibu.

Dari hasil wawancara ini terlihat jelas bahwa posisi perempuan sebagai pemimpin adalah dalam posisi pengganti, apabila tidak ada laki-laki yang mampu. Kedudukan perempuan tetap tidak setara dengan laki-laki. Peran gender tradisional tetap berlaku dalam kontruksi perempuan dan kepemimpinan dalam gerakan ini di mana posisi pemimpin adalah ranah lakilaki dan perempuan adalah di bawahnya, walaupun menurut salah seorang responden hal itu 
hanya dalam ranah Islam karena dalam ranah demokrasi peran gender tradisional bisa saja tidak berlaku, seperti kata Okt. dalam wawancara.

Dalam hal kepemimpinan perempuanan pun, Gerakan Tarbiyah juga sudah mempunyai acuan bagi para aktivis perempuan. Dalam buku Takariawan (2010) terlihat jelas bahwa perempuan adalah warga negara yang aktif tidak hanya dalam ranah privat tetapi juga dalah ranah publik. Yang tentang kepemimpinan perempuan adalah bahwa gerakan ini secara ideal memperbolehkan perempuan menjadi pemimpin asalkan bukan pemimpin negara (Takariawan dkk 2010):

Pada sebagian kalangan kaum muslimin terdapat pemahaman bahwa para akhwat muslimah hendaknya lebih banyak tinggal di rumah, dan tidak boleh mengambil peran kepemimpinan publik karena dianggap bukan merupakan wilayah kaum perempuan. Mereka menggunakan argumen firman Allah:

"Dan hendaklah kamu tetap di rumahmu" (Al Ahzab:33).

Padahal para mufasir memahami bahwa ayat ini ditujukan kepada isteri-isteri Nabi saw. Kendati demikian, Aisyah ra, perempuan yang paling mendalam pengetahuan agamanya, tidak merasa terhalang keluar rumahnya, dari Madinah menuju Basrah, memimpin pasukan yang di dalamnya ada pasukan laki-laki, dua di antaranya termasuk dalam sepuluh orang yang dijamin masuk surga. Dengan demikian ayat ini tidak bisa digunakan untuk dalil pelarangan perempuan dalam kancah sosial maupun politik.

Sekalipun pada contoh perang Jamal tersebut Aisyah kemudian menyesali apa yang telah diperbuatnya, hal itu bukan karena perbuatannya dipahami sebagai melanggar syariat. Penyesalan itu, menurut Yusuf Al Qardhawi, disebabkan oleh ketidaktepatan dalam mengambil keputusan politik. Berarti ini merupakan masalah lain.

Ibnu Hazm seorang ulama madzhab Hanbali dalam kitab Al Muhalla berpendapat bahwa jabatan yang tidak boleh diserahkan kepada perempuan hanyalah ri'asah ad daulah atau pemimpin negara. Kepemimpinan dalam wilayah umum seperti itu di mana padanya bermuara seluruh urusan kaum muslimin, tidak diberikan kepada perempuan. Tetapi para ulama berbeda pendapat tentang pengangkatan perempuan di luar khalifah atau pemimpin tertinggi dalam suatu negara, dengan demikian, menurut Qardhawi, dalam hal ini terbuka pintu ijtihad.

Dalam kaitan dengan kepemimpinan perempuan, Dr. Yusuf Qardhawi berpendapat bahwa kepemimpinan kaum laki-laki atas kaum perempuan lebih cenderung kepada permasalahan kehidupan dalam keluarga. "Adapun kepemimpinan sebagian perempuan atas sebagian lakilaki di luar lingkup keluarga, tidak ada nash yang melarangnya. Dalam hal ini, yang dilarang adalah kepemimpinan umum seorang perempuan atas kaum laki-laki", demikian pendapat Yusuf Qardhawi.

Dengan demikian para akhwat harus disipkan untuk mengemban amanah kepemimpinan dalam berbagai urusan, khususnya yang menyangkut masalah kaum wanita. Tarbiyah Islamiyah mencetak bukan saja kader, akan tetapi pemimpin yang memiliki potensi dan ketrampilan dalam memimpin.

Kalau dicermati memang terdapat gap antara wacana dan realita. Dari hasil wawancara dengan para responden perempuan, mereka lebih banyak memilih untuk meletakan kepemimpinan di tangan laki-laki walaupun sebenarnya dalam buku panduan tidak menutup kepemimpinan perempuan kecuali kepemimpinan umum perempuan atas laki-laki, tetapi atas sebagian laki-laki tidak ada aturan yang melarang.

\section{Relasi gender dalam ranah publik}

Dalam ranah publik, cuplikan wawancara berikut sudah menggambarkan relasi gender (antara perempuan dan laki-laki dalam gerakan ini). Menurut Faj.:

Seperti yang saya bilang tadi bahwa laki- laki itu ya pemimpin itu sendiri, dia yang memimpin kita sedangkan perempuan itu ya untuk pendamping dari laki- laki itu sendiri, tapi perempuan itu juga tidak bisa dikesampingkan, maksudnya porsinya lebih rendah itu tidak, tapi sebenernya posisi kita itu sejajar, karena kita saling mendampingi 
Menurut Mah.:

Yang pasti memang laki- laki dan perempuan ini, sesuatu yang nggak bisa disamakan ya karena memang berbeda, tugasnya juga berbeda jadi untuk pemisahnya itu semisal kita dalam satu forum, otomatis kita nggak bisa dengan leluasa Menurut Okt. lagi: berkomunikasii. Tapi tapi bukan berarti komunikasi kita terbatas.

Misalkan nggak mungkin lah seorang wanita akan naik- naik masang spanduk, jelas itu jelas pekerjaannya lelaki. Itu yang mengerjakan laki- laki. Terus kalau misalkan caranya komunal, ya yang jadi MC dan segala macam yang istilahnya tampil di depan itu kebanyakan laki- laki. Yang perempuan ya mungkin bantu- bantu di administrasi. Dan yang lainnya, di konsep- konsep yang lainnya, kayak gitu. Cuma kalo memang hal- hal yang istilahnya berat dan itu pekerjaannya laki- laki ya itu yang ngerjain laki- laki.

Menurut Yul.:

Yang pertama perempuan sebenarnya itu ya kan kita sering medengar istilah perempuan itu pilar peradaban, perempuan itu itu tiangnya negara. Memang benar perempuan itu, maksudnya ya memang kita itu dalam aturan Islam juga mengakui bahwa laki-laki sebagai pemimpin, sedangkan perempuan tetapi di sini kan, besok kita kan berkeluarga. La di situ kita akan menjadi istri la di situ istri akan membawa peran, peran utama di dalam keluarga. Di mana akan menjadi semangat bagi suaminya, akan mendidik anak-anaknya. Untuk bisa, untuk bisa menciptakan generasi, genersi baru yang bisa membangun bangsa ini di mana ... kita sendirikan punya ibu, ibu kan sebagai figur bagi kita, maksudnya ibu kan bagi kita segalagalanya yang mengajarkan kita, yang mendidik kita, kalau kita kehilangan sosok ibu sendiri pasti ada hal yang berbeda dari diri kita. Karena memang ibu sosok paling deket dengan kita gitu. La di situ seorang ibu akan mendidikan nilai-nilai pertama untuk anaknya, di mana kalau ibu itu salah mendidik maka nilai yang tertanam dalam anaknya itu juga salah.

Ditambah pendapat Fiq.:

Yang jelas bahwasanya, di dalam Al Quran sendiri eh antara ba'du qum mim ba'di maksudnya adalah perempuan dan laki - laki itu saling mengisi, harusnya konsepnya seperti itu di mana antara laki - laki dan perempuan ini saling mengisi bukan berarti laki - laki menggunakan kelebihannya untuk menindas perempuan dan juga yang paling penting adalah knsep bagaimana apa yang Allah ciptakan tu baik itu memiliki porsi yag sama kodratnya itu sama kewajiban dan haknya itu, kewajibannya sama hanya saja memiliki kelebihan masing - masing yang itu berbeda satu sama lain, kembali lagi ba'duqum mim ba'di itu kembali lagi. Konsepnya itu seperti itu bukan untuk antara superioritas dengan subordinat gitu, bukan seperti itu tapi eh harusnya sama gitu, konsepnya seperti itu.

Dalam semua wawancara terbaca bahwa perempuan dan laki-laki secara biologis berbeda dan perbedaan ini menghasilkan sexual division of labour. Tempat perempuan adalah di rumah: memasak, mengasuh anak menjadi ibu dan fungsi-fungsi nurturing lainnya. Sedangkan lakilaki adalah punggawa ranah publik yang memang ditakdirkan untuk memimpin. Dalam konteks feminism perbedaan seperti ini merupakan bagian dari apa yang dikenal sebagai konsedp difference feminism atau cultural feminism: konsep yang menyatakan bahwa perempuan dan laki-laki secara gender adalah berbeda tetapi saling melengkapi.

Cultural feminism: Focuses on women's inherent differences from men, including their "natural" kindness, tendencies to nurture, pacifism, relationship focus, and concern for others. Opposes an emphasis on equality and instead argues for increased value placed on culturally designated "women's work."

Difference feminism: Emphasizes women's difference/uniqueness and traditionally "feminine" characteristics; argues that more value should be placed on these qualities (Types of Feminism).

Satu hal menarik yang terlihat dalam semua wawancara adalah bahwa semua responden lakilaki tidak merasa tidak ada masalah apabila perempuan setara dengan mereka artinya 
perempuan memimpin tidak bermasalah dan telah terdapat kesetaraan gender dalam ajaran gerakan ini (perempuan walaupun duduknya terpisah dari laki-laki tetapi mereka tetap boleh berpendapat dalam fokus yang terdapat anggota laki-laki) tetapi semua responden perempuan mengatakan bahwa perempuan dan laki-laki juga setara tetapi perempuan tetap harus di belakang laki-laki, "Kalau menurut saya emansipasi wanita itu bagus dalam persamaan derajat tapi kalau kalau persamaan kodrat itu yang bisa diperdebatkan" (wawancara dengan Fah.).

Bagi perempuan sendiri (semua responden perempuan) perempuan adalah invisible (tidak nampak atau dididik untuk tidak nampak.invisible dalam ranah publik dan/atau bila berhubungan dengan relasi gender). Bagi responden laki-laki perempuan bisa visible tetapi bagi responden perempuan, idealnya perempuan tetap harus invisible apabila terdapat relasi dengan gender lain (laki-laki).

\section{Perempuan sebagai anggota umat}

Keanggotaan perempuan dalam gerakan ini juga menunjukkan hal-hal yang menarik. Dengan fungsi reproduksinya gerakan Tarbiyah memang membuat perempuan bekerja sejalan dengan fungsi reproduksi: perempuan apabila telah berumah tangga diajarkan untuk mempunyai anak sebanyak mungkin (menurut Yul.).

Hal ini merupakan strategi anggota gerakan ini untuk menambah jumlah populasi. Kuantitas anggota gerakan ini menjadi salah satu jawaban atas pertanyaan mengapa para ikhwan dan akhwat dalam gerakan ini cenderung melakukan perkawinan sesegera mungkin setelah lulus dari jenjang universitas dan mengapa mereka cenderung mempunyai jumah keturunan yang sangat banyak. Penambahan populasi menjadi strategi yang sangat penting dalam pengembangan cakupan gerakan ini. Walaupun kebijakan ini nampaknya tidak sejalan dengan Program Keluarga Berencana (PKB) yang menjadi agenda pemerintah tetapi nampaknya pemerintah juga tidak melakukan sesuatu akan hal ini.

Dan sebagai anggota umat, peranan perempuan cukup signifikan di dalam gerakan ini. Perempuan adalah kader. Sebagai kader, selain mereka bertanggungjawab mengembangkan kualitas anggota yang dikader tetapi juga kuantitasnya sehingga tidak heran jumlah anak yang banyak dalam suatu keluarga yang orangtuanya adalah anggota gerakan ini menjadi strategi yang jitu. Dalam hal ini, perempuan setara dengan laki-laki, dalam fungsi mereka sebagai umat. Kaderisasi adalah kewajiban setiap anggota gerakan, seperti dikatakan dalam "Tarbiyah antara Nukhbawiyah dan Jamahiriyah":

(1) Tarbiyah Nukhbawiyah. Tarbiyah nukhbawiyah [pembinaan kader] merupakan kelanjutan dari Tarbiyah jamahiriyah [kaderisasi massa] yang berfungsi untuk saling melengkapi dan tidak boleh dipisah antara yang satu dengan yang lainnya. Tarbiyah nukhbawiyah adalah kaderisasi yang difokuskan kepada orang-orang tertentu hasil rekruting massa dan bertujuan untuk mempersiapkan para da'i dan murobbi di tengah-tengah masyarakat serta untuk masyarakat. Bila hal ini tidak menjadi tujuan Tarbiyah, maka Tarbiyah nukhbawiyah hanya sebagai kegiatan rutinitas terbatas pada ishlahul fardi [perbaikan pribadi] yang ekslusif, bahkan kebaikan yang bersifat pasif, karena tidak memiliki peran perbaikan terhadap masyarakat dan realita kehidupan. Tarbiyah nukhbawiyah bertujuan meningkatkan berbagai kemampuan dan keahlian kader agar dapat berperan dalam mengendalikan dan merekrut massa di bidang tarbiah, da'wah, harokah dan siasah serta mampu menyiapkan masyarakat agar siap melakukan gerakan reformasi dan perubahan. Tetapi tidak semua orang harus atau dipaksakan mengikuti Tarbiyah nukhbawiyah karena potensi, kemampuan dan kesiapan manusia tidaklah sama. Selain itu tidak semua orang memiliki kesiapan untuk menjadi aktifis da'wah. Pandangan yang jauh ke depan, kejernihan hati, bijak, sabar, mencintai orang lain dan bersemangat membimbing mereka, tawakkal kepada Allah serta ikhlash hanya menginginkan balasan dariNya adalah sifat-sifat yang harus 
ada pada seorang da'i. Sehingga ia mampu membuat sesuatu yang dibenci menjadi disenangi, yang jauh menjadi dekat dan lawan menjadi kawan. Dan (2) Tarbiyah Jamahiriyah. Tarbiyah nukhbawiyah adalah follow up atau tindak lanjut dari Tarbiyah jamahiriyah. Ia merupakan motor penggerak Tarbiyah jamahiriyah dan sekaligus mengarahkan, meluruskan serta mengendalikannya, jadi bukan sebagai pengganti atau sesuatu yang kontradiktif. Sementara Tarbiyah jamahiriyah adalah mengaktualisasikan peran Tarbiyah nukhbawiyah dengan tabligh, nasyrul fikroh dan mengajarkan Islam kepada masyarakat sehingga mereka menjadi pendukung da'wah dan terjadilah proses tajmi' jamahiri [rekruting massa]. Bila hal itu tidak terjadi berarti Tarbiyah nukhbawiyah telah gagal karena Tarbiyah menjadi tidak punya peran dan tujuan.

Melalui halaqoh (lingkaran) dan liqo' (pertemuan) yang merupakan forum yang sangat efektif dalam penyebaran gerakan ini karena melalui forum ini penanaman keyakinan dan proses pembentukan kepribadian anggota gerakan ini terlaksana (Al-Bilali 2000). Sistem kaderisasi ini terbukti membuat gerakan ini bertahan hingga kini. Kader perempuan dan laki-laki mempunyai tanggung jawab yang sama sebagai umat dan anggota gerakan ini.

Sebagai kader perempuan juga mempunyai fungsi yang politis dalam ranah publik. Bahkan sebagai perempuan kedudukannya tidak boleh diabaikan, seperti kata Cho:

Karena kedudukannya sangat penting peranannya. Seperti kita ketahui dalam hadist bahwa wanita itu tiang agama, dan anak yang terlahir menjadi seorang hebat itu berkat dari Tarbiyah seorang ibu. Aisyah perannya pintar dalam ribuan haidist, Ummu Salamah yang ikut berperang bersama Rasulullah. Jadi kedudukan wanita itu sangat penting, menurut saya, versi saya.

Menurut Rif:

Posisi perempuan tidak hanya dalam Tarbiyah saja, dia itu posisi yang sangat istimewa dihadapan Allah SWT. Terlihat bagaimana Al Qur'an hanya ada Surat An Nisa,' Ar Rizal itu tidak ada. Dan seumpama kalau kita lihat ada Surat Maryam juga, berarti kan ada sesuatu di balik perempuan itu diistimewakan oleh Allah SWT. Terlepas itu juga pribahasa yang mengatakan kalau seumpama kita ingin mengkader seorang laki-laki kita hanya mengatur satu orang saja, kalau kita mengakder seorang akhwat ibarat kita mengatur sepuluh umat. Karena dari perempuan itu sendiri luar biasa potensi yang diberikan. Apalagi ada yang mengatakan bahwasannya negara itu akan baik jikalau perempuannya itu baik. Itu sudah menganalogikan bahwa perempuan ini diistimewakan yang baik. walaupun mungkin dalam konteks kepemimpinan atau apa berbeda halnya dengan laki-laki. Kalau laki-laki memang disiapkan untuk menjadi pemimpinnya wanita. itu memang sudah seperti itu. Jikalau wanita ini dipimpin utk menjadi seorang pemimpin, maka wanita ini belum tentu seoerti apa yang menjadi alurnya dari seorang laki-laki. Katakanlah dia pasti halangan tiap bulannya, kalau laki-laki tidak. Itu salah satu hal yang wajar bagi perempuan dan secara tingkatannya lebih tinggi tingkatannya adalah seorang lai-laki.

Dari wawancara di atas maupun wawancara-wawancara lainnya terlihat bahwa sebagai kader perempuan berkedudukan sangat penting karena menjadi bagian dari agama dan penerus generasi sehingga kaderisasi mejadi sarana untuk pemberdayaan perempuan dan rekognisi atas pentingnya perempuan dalam gerakan ini. Yang menarik untuk dicermati dari wawancara di atas adalah bahwa perempuan teladan dalam gerakan ini bukannya perempuan yang hanya berfungsi sebagai ibu rumah tangga tetapi adalah perempuan yang mempunyai peranan politik yang sangat kuat dalam ranah publik. 


\section{Perempuan dalam ranah domestik}

\section{Perempuan "ideal”}

Peranan perempuan difokuskan atau diutamakan dalam wilayah domestik sehingga gambaran perempuan ideal adalah seorang ibu dan perempuan sesuai dengan konstruksi gendernya, seperti kata Lut:

Perempuan yang ideal itu melaksanakan yang sudah menjadi kodratnya. Kalau perempuan ya kodratnya perempuan, yang lembut penuh aksih sayang,Yang tidak melebihi laki-laki. . . Kalau dari segi sikap mungkin menunjukkan lah kalau..misalnya cara berdiri ya apa.. cara duduk yang pantas, untuk perempuan seperti apa posisinya, cara bergaul seperti apa, pokoknya bisa menempatkan diri bagaimana cara bergaul dengan perempuan yang lain dengan orang yang lebih tua maupun dengan laki-laki.

Menurut Okt.

Ya, memang yang ideal memang seperti Rasulullah, tapi nggak ada orang yang bisa menyerupai rasulullah kayak gitu, kalo menurutku sederhana saja seh ya dia mampu bertanggungjawab. Kalo perempuan ideal ituu eeeh apa ya? Istilahnya dia mampu mendidik anak- anaknya. Dia kalo misalkan dia belum punya anak ya, dia perempuan yang ideal itu yang mampu menjaga dirinya menjaga izzah dan iffahnya terus dia juga apa ya istilahnya mampu eeeh gimana ya mapu eeeh mampu bermanfaat untuk sekitar terus eeehhh penyayang, hatinya lembut Wanita itu terkenal dengan lemah lembut dan penyayangnya itu.

Responden di atas menjelaskan bahwa perempuan ideal adalah perempuan yang menjalani fungsi domestik, nurturing dengan segala kefeminitasnya.

Yang lebih menarik adalah hampir semua responden perempuan dan laki-laki melihat lebih obyektif adanya perempuan ideal. Sebagian besar responden menjawab bahwa sosok perempuan ideal bersifat relatif dan sebagian besar responden tidak mempunyai contoh perempuan ideal tetapi untuk laki-laki ideal ada sebagian yang memilih Muhammad SAW sebagai laki-laki ideal sedangkan sebagian lain menjawab tidak ada atau relatif. Lebih menarik lagi sebagian besar responden menunjukkan obyektifitas dalam menilai laki-laki atau perempuan ideal dengan mengatakan bahwa semua manusia (baik laki-laki dan perempuan) mempunyai kelemahan dan kelebihan masing-masing dan mereka yang mampu berfungsi sebagai manusia yang berguna inilah yang disebut ideal seperti kata Ram.

Kenapa nggak ada [perempuan ideal], karena di prinsip saya sendiri kayak setiap orang pasti punya plus dan minus kayak gitu, tapi cuma mungkin bukan ideal, mungkin aku bilang dia bisa jadi role model kayak gitu, untuk aku sendiri menemukan titik sebagai ini perempuan yang pas itu tergantung konteks, ini perempuan ideal itu tergantung konteks, kayak semisal ini perempuan yang ideal sebagai ibu rumah tangga, ini perempuan yang ideal sebagai kayak perempuan yang karir kayak gitu, jadi itu tegantung sesuai konteks sih kalo menurut kata- kata ideal itu nggak bisa kayak digeneralisasi.

\section{Kata Fit.:}

Yang agamanya bagus, itu yang kalo, sholeh sholehah, terus pinter, cerdas maksudnya. 
Menurut Feb.:

Perempuan ideal itu ya tadi menjalankan kewajibannya sesuai dengan ajaran Islam. Kalau perempuan ideal itu memang kalau menentukan baik tidaknya itu seperti di Qur'an disebutkan adalah yang ketaqwaannya paling baik, bukan kepintarannya dan bukan pula kecantikannya. Dan ketaqwaan sudah dijalankan pasti ajaran Islam itu dia jalankan.

Menurut Ij.:

Nah perempuan yang ideal yang kedua itu adalah perempuan yang meskipun wawasannya luas dia tetap kontribusi dalam negara juga besar dia juga tetap tidak lupa juga sebagai kodrat perempuan secara Islam ya. . . Nah padahal memang mereka [perempuan] nanti bakal mengurus rumah, ya itu kan kewajiban juga kalau di budaya kita kewajiban perempuan kalau mengurus rumah. Tapi ya, jadi pengurus rumah itu tidak harus diam tanpa ilmu, mereka juga bisa berkarya di dalam rumah pun. Ya tidak hanya berkarya sebagai pelayan suaminya doang, tetapi juga sebagai karya menghasilkan sesuatu yang produktif itu di dalam rumah. Kan banyak perempuan yang menghasilkan sesuatu, tetapi tetap di rumah gitu, misalkan membuat kue, membuat ini-itu.

Setidaknya dari wawancara-wawancara di atas para responden melihat sosok atau bentuk perempuan ideal bukanlah dari segi fisik tetapi lebih pada moralitas dan karakter serta kompetensi. Hal ini sebenarnya hampir sama dengan banyak acuan budaya popular seperti dalam majalah-majalah remaja, majalah-majalah perempuan yang selalu menekankan bahwa perempuan ideal terletak pada faktor kualitas mental dan moral.

\section{Gender dan kesalehan}

Mengikuti pandangan para repsonden, kesalehan perempuan dan laki-laki adalah ukuran akan nilai reigiusitas para anggota Tarbiah ini. Bagi responden perempuan kesalehan perempuan menandai idealnya seorang perempuan tersebut. Kesalehan perempuan adalah variabel utama kesempurnaan perempuan seperti yang termodelkan dari putri dan istri Nabi Muhammad. Perempuan yang saleh adalah perempuan yang berada atau mengutamakan ranah domestik sesuai dengan ajaran yang mereka terima lewat halaqoh dan liqo' serta perempuan yang mempunyai kualitas keagamaan yang tinggi. Faktor seperti jujur, setia, sabar, teguh, mulia, tidak sombong adalah kualitas kesalehan perempuan sekaligus kesempurnaan perempuan.

Bagi responden laki-laki juga demikian, mereka melihat variabel utama ukuran kesalehan adalah ketertundukan seorang individu pada aturan-aturan yang dibuat Allah. Kata Tat.:

Allah juga akan mengangkat derajat orang yang berilmu dan amalnya tentunya, tidak mungkin orang itu menjadi mulia karena ilmunya saja karena ilmu dan amal itu suatu hal yang harus berdampingan.

Dari hasil wawancara terlihat bahwa perempuan dalam gerakan Tarbiyah terkategorikan atas 2 hal yaitu ranah privat dan kualitas kepribadian. Sebagai bagian dari domestikasi mereka harus menurut, taat, sekaligus setia. Pilihan kata-kata yang terlihat dari wawancara-wawancara tersebut menunjukkan bahwa kesalehan perempuan berada dalam wilayah domestik karena kata-kata seperti tersebut di atas adalah kata-kata yang secara umum terasosiasi dengan wilayah domestik, privat dan erat kaitannya dengan femininitas. Berbeda dengan pegambaran ideal laki-laki yang menurut responden laki-laki bahwa mereka yang kuat, sehat, tabah, pintar, cendekia, adalah kualitas ideal laki-laki: kata-kata yang berasosiasi dengan wilayah publik yang menandai maskulinitas seperti kekuatan fisik. Kesalehan perempuan bukan konsumsi publik yang harus dipertontonkan atau ditunjukkan ke publik. Kesalehan perempuan harus invisible seperti kedudukan perempuan itu sendiri. 


\section{Konstruksi gender dan modalitas pembangunan karakter bangsa}

Seperti dalam uraian sebelumnya tentang pentingnya konstruksi gender sebagai modalitas pembangunan karakter bangsa terlihat jelas dalam ajaran-ajaran gerakan ini. Ajaran-ajaran yang ada yang oleh responden disebut sebagai 10 Muwashofat Kader Dakwah (menurut Ist.) ternyata erat atau sangat berkelindan dengan 18 nilai pendidikan karakter bangsa. Dalam Muhajir (2012) disebutkan bahwa 10 Muwashofat Kader Dakwah adalah:

Kepribadian seorang Muslim haruslah berlandaskan Al Quran dan As sunnah. Karena keduanya merupakan warisan Rasulullah untuk ummatnya, dari Allah SWT. Bila disederhanakan, sekurang-kurangnya ada sepuluh profil atau ciri khas yang harus lekat pada pribadi Muslim.

1) Salimul Aqidah (Aqidah yang bersih), 2) Shahihul Ibadah (Ibadah yang benar), 3) Matinul Khuluq (Akhlak yang kokoh), 4) Qowiyyul Jismi (Kekuatan jasmani), 5) Mutsaqqoful Fikri (Intelek dalam berpikir), 6) Mujahadatul Linafsihi (Berjuang melawan hawa nafsu), 7) Harishun Ala Waqtihi (Pandai menjaga waktu), 8) Munazhzhamun fi Syuunihi (Teratur dalam suatu urusan), 9) Qodirun Alal Kasbi (Memiliki kemampuan usaha sendiri atau yang juga disebut dengan mandiri), dan 10) Nafi'un Lighoirihi (Bermanfaat bagi orang lain).

Dari 10 ajaran tersebut, semuanya erat dengan pembangunan karakter bangsa yang menandai karakter civil society. Ada disiplin, kejujuran, pembangunan kekuatan fisik, bahkan kemandirian merupakan ajaran-ajaran yang sangat kuat bagi pembangunan karakter bangsa melalui ajaran agama (dalam hal ini adalah Islam). Oleh karena itu hal ini bisa menjadi salah satu alternatif modalitas pembangunan karakter bangsa melalui pendidikan informal atau organisasi yang dibangun dan swasembada masyarakat.

Bagi aktivis perempuan Gerakan Tarbiyah juga sudah mempunyai panduan yaitu buku yang berjudul Keahwatan 1 - 4 yang ditulis oleh Takariawan dkk (2010). Panduan pembentukan karakter yang ada bagi aktivis perempuan dalam empat buku ini ternyata serupa (bisa dikatakan sama) dengan 28 karakter bangsa yang dimaksudkan, bahkan dalam buku-buku tersebut para aktivis dididik untuk menjadi manusia yang berkontribusi untuk bangsa, negara dan bahkan peradaban.

\section{Simpulan}

Hasil yang dapat disimpulkan dari penelitian ini adalah bahwa konstruksi gender yang muncul Sexual division of labour masih berlaku dalam ajaran gerakan ini walaupun para anggotanya sudah mengusung nilai-nilai civil society (masyarakat madani). Pemisahan perempuan dan laki-laki yang terjadi tidak hanya menandai separation of space tetapi juga separation of piety di mana kesalehan laki-laki dan perempuan diukur.

Perempuan berada dalam wilayah domestik, privat dan invisible juga menandai konstruksi mereka. Sedangkan laki-laki berada dalam oposisi atau wilayah seberangnya. Walaupun perempuan dan laki-laki dipisah tetapi mereka tetap setara di hadapan Tuhan maupun hukum. Perempuan seperti laki-laki boleh menjadi pemimpin walaupun perempuan hanya boleh memimpin sesama perempuan dan laki-laki boleh memimpin perempuan dan laki-laki.

Ketertundukan yang total terhadap hukum dan system mentoring membuat gerakan Tarbiyah menjadi salah satu modal pembentukan karakter bangsa. Ajaran-ajaran yang ada dalam gerakan Tarbiyah bisa menjadi salah satu modalitas pembangunan karakter bangsa karena ajaran-ajaran tersebut sangat erat dengan 18 karakter bangsa sebagaimana yang dimaksudkan yaitu: religius, jujur, toleransi, disiplin, kerja keras, kreatif, mandiri, demokratis, rasa ingin tahu, semangat kebangsaan, cinta tanah air, menghargai prestasi, bersahabat/komunikatif, cinta damai, gemar membaca, peduli lingkungan, peduli sosial dan tanggung jawab. Walaupun sering distereotipekan sebagai Islamis ternyata gerakan Tarbiyah penuh dengan 
nilai-nilai universal kemanusiaan serta demokrasi yang tidak jauh berbeda dengan nilai-nilai humanism Barat. Perbedaannya terletak pada bingkai agama yang menjadi rumah dari nilainilai ini. Hal ini erat dengan panduan gerakan Tarbiyah bahwa Islam adalah rahmat bagi sekelilingnya tidak peduli bagaimana berbedanya sekelilingnya tersebut. Konstruksi gender dalam gerakan Tarbiyah bisa menjadi salah satu alternatif pendidikan kararter bangsa melalui institusi informal dan religius.

\section{Daftar Pustaka}

Abubakar I (2002) Islam and gender books published in Indonesia (1990 - 2003). Kultur: The Indonesian Journal For Muslim Cultures 2 (2):131-148.

Al-Bilali AH (2000) Program dan solusi kaderisasi. Jakarta: Era Media.

Brenner S (1996) Reconstructing self and society: Javanese muslim women and "the Veil". American Ethnologist 23 (4):673 - 695.

Bruinessen MV (2002) Genealogies of Islamic radicalism in post-Suharto Indonesia. South East Asia Research 10 (2):117-154.

Bruinessen MV (2003) Post-Suharto Muslim engagements with civil society and democracy. Dalam Seminar Third International Conference and Workshop "Indonesia in Transition"24-28 Agustus 2008. Depok: Universitas Indonesia.

Carpenter M (2001) Muslim women say veil is more about expression than oppression. [Diakses 16 November 2005] http://www.post-gazette.com.

Cooke M (2001) Women claim Islam creating Islamic Feminism through literature. New York: Routledge.

Damanik AS (2002) Fenomena partai keadilan transformasi 20 tahun gerakan tarbiyah di Indonesia. Jakarta: Penerbit Teraju.

Dayat G (2008) Beda Salafi Beda Tarbiyah. 8 Mei 2008. Gus Dayat: Blog [Diakses 8 Mei 2008.

Hassan R (1996) Feminist theology: The challenges for Muslim Women. Critique, Fall. pp. 52 -65 .

Istiadah (1995) Muslim women in contemporary Indonesia: Investigating paths to resist the patriarchal system. Clayton, Victoria, Australia: Monash University, Centre for Southeast Asian Studies.

Meuleman JH (1993) Analisis buku-buku tentang wanita Islam yang beredar di Indonesia. Natsir MM, Meuleman JH (eds). Wanita Islam Indonesia dalam Kajian Tekstual dan Kontekstual, Lies. Jakarta: INIS.

Muhajir S (2013) 10 Muwashofat kader dakwah. [Diakses 21 Oktober 2015]. http://siddiqmuhajir-fk12.web.unair.ac.id/artikel_detail-73155-Islam10\%20muwashofat\%20kader\%20Dakwah.html.

Risalah Gusti (2000) Perspective Islam. Tim Risalah Gusti (ed). Jakarta.

Presiden: Perempuan pilar utama pembangunan karakter bangsa (2010) [Diakses 8 April 2014]. http://www.antaranews.com/berita/238960/presiden-perempuan-pilar-utamapembangunan-karakter-bangsa, diakses tanggal 8 April2014.

Syafruddin D (1994) Argumen supremasi atas perempuan. dalam Ulumul Qur'an. Edisi

Khusus 5 Tahun UQ, Nomor 5 dan 6, Jakarta: PT. Temprint.

Syaikhut T (2007) Ikhwanul Muslimin inspirasi gerakan tarbiyah.[Diakses 10 Oktober 2015] http://syiar.wordpress.com/2007/10/27/ikhwanul-muslimin-inspirasi-gerakanTarbiyah/).

Takariawan C, Sunono A, Ahmadi W, Laila IN (2010) Keakhwatan 1 - 4. Jakarta: Era Intermedia.

Tarbiyah Antara Nukhbawiyah dan Jamahiriyah, www.images.akhibrahim.multiply.multiplycontent.com).

Tarbiyah Bukan KPS [Diakses 21 Oktober 2015] http://Tarbiyahbukanpks.com.

Toyyibah Q (2015) [Personal Communication] 28 April.

Types of Feminism, [Diakses 21 Oktober 2015] 
http://sparkcharts.sparknotes.com/womens/womens/section4.php.

Wikipedia: Tarbiyah (2015) [Diakses 10 Oktober 2015]

https://id.wikipedia.org/wiki/Tarbiyah.

Women's Studies [Diakses 21 Oktober 2015].

http://sparkcharts.sparknotes.com/womens/womens/section4.php.

Yamani M (ed) (1996) Introduction. feminism and Islam: Legal and literary perspectives.

United of Kingdom, Reading: Itacha Press. 